\title{
Psikografis dan Religiusitas dalam Bertransaksi Pada BNI Syariah Makassar
}

\author{
Muhammad Fauzi Amiruddin, Muh. Wahyuddin Abdullah \\ Universitas Islam Negeri (UIN) Alauddin Makassar \\ fauriamiruddinn@gmail.com
}

\begin{abstract}
This study aims to determine the influence of psychographic factors that include activity, interest and opinion, as well as the religiosity factor to the decision to transact at the BNI Syariah Makassar. This type of research is quantitative research with correlational approach. The data used are primary data through direct questionnaire distribution, using non probability sampling and accidental sampling technique, totaling 56 samples. The respondents of this research are customers who use BNI Syariah products, then the analysis technique used is multiple regression. The result of this study indicates that the variables of activity, interest, opinion, and religiosity simultaneously affect the decision to transact at BNI Syariab Makassar. Partially, this research indicates that the variable of activity, opinion, and religiosity have an effect on the transaction decision, while the interest variable has no effect to the transaction decision at BNI Syariah Makassar. The implication of this research is that transaction activity in syariah bank has become activity which often done by society because the products owned by BNI Syariah Makassar bank have been able to support the society activity. The Society opinion on BNI Syariah bank is also positive, and the existence of BNI Syariah bank has become a solution for people who have high level of religiosity. To evaluate the issue of the society interest, BNI Syariah Makassar Bank should maximize the Information and Promotion media to attract the public interest.
\end{abstract}

Keywords: Activity, Interest, Opinion, Religiosity, Syariab Transaction

\begin{abstract}
Abstrak
Penelitian ini bertujuan untuk mengetahui pengaruh faktor psikografis yang meliputi aktivitas, minat dan opini, serta faktor religiusitas terhadap keputusan bertransaksi pada BNI Syariah Makassar. Jenis penelitian ini adalah penelitian kuantitatif dengan pendekatan korelasional. Data yang digunakan adalah data primer melalui penyebaran kuesioner secara langsung, dengan menggunakan teknik non probability sampling dan accidental sampling, berjumlah 56 sampel. Responden penelitian ini adalah nasabah yang menggunakan produk BNI Syariah, selanjutnya teknik analisis yang digunakan adalah regresi berganda. Hasil
\end{abstract}

Al Falah: Journal of Islamic Economics, Vol. 3, No. 1, 2018

STAIN Curup|E-ISSN: 2548-3102, P-ISSN: 2548-2343

Available online: http://journal.staincurup.ac.id/index.php/alfalah 
penelitian ini menunjukkan bahwa variabel aktivitas, minat, opini, dan religiusitas secara simultan berpengaruh terhadap keputusan bertransaksi pada BNI Syariah Makassar. Secara parsial, penelitian ini menunjukkan bahwa variabel aktivitas, opini, dan religiusitas berpengaruh terhadap keputusan bertransaksi, sedangkan variabel minat tidak berpengaruh terhadap keputusan bertransaksi pada BNI Syariah Makassar. Implikasi penelitian ini bahwa kegiatan transaksi di bank syariah sudah menjadi kegiatan yang sering dilakukan oleh masyarakat karena produk-produk yang dimiliki BNI Syariah Makassar sudah mampu menunjang aktivitas masyarakat. Opini masyarakat terhadap BNI Syariah juga positif, dan keberadaan BNI Syariah sudah menjadi solusi bagi masyarakat yang memiliki tingkat religiusitas tinggi. Untuk mengevaluasi terkait masalah minat masyarakat, BNI Syariah Makassar harus lebih memaksimalkan media Informasi dan promosi untuk menarik minat masyarakat.

Kata Kunci: Aktivitas, Minat, Opini, Religiusitas, Transaksi Syariah

\section{PENDAHULUAN}

Perkembangan lembaga keuangan syariah terus terus mengalami peningkatan, Tercatat hingga Agustus 2017 asset keuangan syariah telah mencapai Rp.1.048,8 triliun, jumlah tersebut jika dibandingkan dengan total asset keuangan nasional yang mencapai Rp. 13.092 triliun, berarti pangsa pasar syariah per Agustus 2017 telah mencapai angka $8 \%$. Jumlah asset tersebut terdiri atas asset perbankan syariah Rp. 389,74 triliun, pasar modal syariah 559,59 triliun, dan lembaga keuangan non bank 99,15 triliun ${ }^{1}$. Meski Pasar modal syariah menjadi pemilik asset dan penyumbang pangsa pasar terbesar, penulis lebih tertarik untuk membahas perbankan syariah yang memiliki pangsa pasar yang telah mencapai $5,44 \%$. Hal ini karena pangsa pasar perbankan syariah telah melebihi target yang telah dicanangkan Direktorat Perbankan Syariah pada tahun 2002 yaitu sebesar 5 $\%{ }^{2}$. Selain itu, Perbankan syariah sering dianggap sebagai leader dalam industri jasa keuangan syariah karena merupakan industri yang pertama lahir dan tumbuh dalam keuangan syariah ${ }^{3}$.

\footnotetext{
${ }^{1}$ Kunthi Fahmar Sandy, "Pangsa Pasar Keuangan Syariah Tembus 8\%," SINDOnews.com, $\quad$ accessed October 29, 2017, https://ekbis.sindonews.com/read/1252673/178/pangsa-pasar-keuangan-syariahtembus-8-1509271447.

2Sutrisno, "Membangun Model Lembaga Keuangan Syariah," Jurnal Ekonomi Dan Bisnis Islam 7, no. 2 (n.d.): h.145.

${ }^{3}$ Abdul Malik, "Ini Penyebab Pangsa Pasar Perbankan Syariah Tembus 5,46 Persen Pada Juli 2017," accessed November 19, 2017,
} 
Jumlah kelembagaan perbankan syariah terdiri dari 13 bank umum syariah, 21 unit usaha syariah, dan 167 bank pembiayaan rakyat syariah. Sedangkan kelembagaan keuangan syariah non bank terdri atas 59 asuransi syariah, 38 pembiayaan syariah, 6 penjamin syariah, 10 lembaga keuangan mikro syariah, dan 10 lembaga keuangan non bank lainnya. Berdasarkan jumlah kelembagaan, terlihat kelembaan perbankan syariah lebih mengungguli jumlah lembaga keuangan syariah non $\mathrm{bank}^{4}$. Pertumbuhan asset industri perbankan syariah tidak terlepas dari kontribusi tiga bank syariah yaitu Bank Syariah Mandiri, BRI Syariah dan BNI Syariah. Secara kuantitas Bank Syariah Mandiri memang mencatatkan asset 78,8 triliun pada tahun 2016, jauh mengungguli BNI Syariah yang memiliki asset sebesar 29,82 triliun, BRI Syariah 27,69 triliun dan BTN Syariah 15,03 triliun. Namun secara kualitas BNI Syariah mengungguli pertumbuhan asset bank lainnya secara year on year yakni sebesar 23,01\% dari tahun sebelumnya, Bank Syariah Mandiri 22,11\% dari tahun sebelumnya dan BRI Syariah 12,49\% dari tahun sebelumnya. Dana pihak ketiga BNI Syariah juga meningkat 25,41\% dibanding periode yang sama pada tahun sebelumnya, mengungguli peningkatan dana pihak ketiga Bank Syariah Mandiri sebesar 24,04\% dan BRI Syariah 11,09\% .

Perbankan syariah saat ini memang tumbuh dengan pesat dibanding lembaga keuangan syariah lainnya, baik dari jumlah asset, jumlah kantor dan bank, jumlah dana pihak ketiga maupun jumlah pembiayaan yang diberikan. Pertumbuhan ini menjadi salah satu indikator bahwa jumlah masyarakat yang memilih menggunakan produk bank syariah semakin meningkat. Keputusan bertransaksi di lembaga keuangan syariah dipengaruhi oleh perilaku konsumen. Setiap nasabah sebagai konsumen jasa lembaga keuangan syariah memiliki pandangan yang berbeda-beda dalam pengambilan keputusan. Untuk mengetahui perilaku konsumen, dilakukan proses segmentasi ke dalam kelompok-kelompok yang memiliki kesamaan karakter dalam pengambilan keputusan ${ }^{6}$.

https://m.bareksa.com/id/text/2017/09/2a2/ini-penyebab-pangsa-pasar-perbankansyariah-tembus-546-persen-pada-juli-2017/16717/news.

"Sandy, "Pangsa Pasar Keuangan Syariah Tembus 8\%."

${ }^{5}$ Elisa Valenta Sari, “Aset Empat Bank BUMN Syariah Mekar Sepanjang 2016," Ekonomi, accessed November 19, 2017, https://www.cnnindonesia.com/ekonomi/20170306074642-78-198035/aset-empatbank-bumn-syariah-mekar-sepanjang-2016.

${ }^{6}$ Esti Dwi Rinawiyanti, Rosita Meitha, and Jeremia Januar Pratama Putra, "Studi Segmentasi Berorientasikan Psikografis dan Behavioral pada Konsumen Fitness Center di Surabaya," JIEMS (Journal of Industrial Engineering and Management Systems) 7, no. 1 (March 16, 2017): 27, doi:10.30813/jiems.v7i1. h.107. 
Pengambilan keputusan oleh konsumen dipengaruhi oleh berbagai faktor, diantaranya Demografis yang meliputi jenis kelamin, usia, pekerjaan, pendidikan dan pendapatan. Geografis yang meliputi kebangsaan, ras, agama dan suku. Psikografis yang meliputi gaya hidup dan kepribadian. Segmentasi yang paling mudah dilakukan adalah melakukan segmentasi pasar berdasarkan faktor demografis dan geografis, karena kedua faktor tersebut dapat terlihat dari luar. Misalnya usia dan jenis kelamin dapat diketahui dari kartu identitas, sedangkan kebangsaan, suku dan ras dapat dilihat dari dialek dan alamat tempat tinggal. Tetapi faktor psikografis tidak terlihat dari luar, karena tidak bisa diketahui secara kasat mata. Perlu dilakukan penelusuran lebih lanjut karena faktor psikografis lebih mencerminkan karakteristik konsumen dan dapat menyiratkan kebutuhan dan keinginan konsumen yang sebenarnya ${ }^{7}$.

Faktor Psikografis dapat digambarkan melalui konsep aktivitas, minat, dan opini. Aktivitas konsumen mengindikasikan apa yang mereka lakukan, apa yang mereka beli dan bagaimana mereka menghabiskan waktu. Aktivitas dapat berupa pekerjaan, hobbi, komunitas dan hal-hal yang berkaitan dengan kegiatan seseorang. Minat memfokuskan diri pada prioritas, kesukaan dan ketertarikan konsumen. Opini mengidentifikasi sudut pandang dan perasaan konsumen mengenai topik-topik peristiwa dunia, lokal, ekonomi dan sosial ${ }^{8}$.

Berdasarkan penelitian sebelumnya, Roza (2014) menemukan aktivitas, minat, dan opini berpengaruh secara simultan dan parsial dalam pembelian produk Tupperware di Jambi'. Sejalan dengan Ekasari (2015) menemukan faktor psikografis secara simultan berpengaruh dalam keputusan pembelian produk Apple, hanya saja secara parsial, variabel minat tidak berpengaruh ${ }^{10}$. Dalam Penelitian Listyorini (2012) justru sebaliknya, variabel aktivitas dan minat tidak berpengaruh dalam pengambilan keputusan pembelian rumah sehat sederhana, dan variabel opini berpengaruh dalam keputusan pembelian rumah sehat sederhana tersebut ${ }^{11}$. Penelitian terhadap religiusitas konsumen, Nasution (2016)

${ }^{7}$ Esti Dwi Rinawiyanti,

8J.C Mowen and Minor, Perilaku Konsumen (Jakarta: Erlangga, 2002), h.283.

${ }^{9}$ Suswita Roza, “Analisis Pengaruh Gaya Hidup Terhadap Keputusan Konsumen Memilih Eco Product (Studi Kasus Pada Konsumen Tupperware Di Kota Jambi) Jurnal Penelitian Universitas Jambi: Seri Humaniora," Jurnal Penelitian Universitas Jambi: Seri Humaniora 16, no. 2 (2014): h.47-58.

${ }^{10}$ Novita Ekasari and Rizky Hartono, "Pengaruh Faktor-Faktor Gaya Hidup Konsumen Terhadap Keputusan Pembelian Laptop Apple," Digest Marketing 2, no. 1 (2015): h.65-71.

${ }^{11}$ Sari Listyorini, "Analisis Faktor-Faktor Gaya Hidup Dan Pengaruhnya Terhadap Pembelian Rumah Sehat Sederhana (Studi Pada Pelanggan Perumahan Puri 
menemukan pengaruh positif religiusitas terhadap keputusan pembelian penganan $\mathrm{Halal}^{12}$. Begitu pula penelitian Shofwa (2015) yang menemukan pengaruh religiusitas dalam pengambilan keputusan nasabah terhadap produk simpanan Bank Syariah Mandiri cabang Purwokerto ${ }^{13}$.

BNI Syariah merupakan anak perusahaan dari PT Bank Negara Indonesia yang melayani kebutuhan perbankan masyarakat Indonesia dengan menggunakan prinsip syariah. Selain pertumbuhan jumlah asset, dana pihak ketiga, peningkatan laba yang turut berkontribusi dalam pertumbuhan lembaga keuangan syariah, BNI Syariah juga telah tercatat memiliki 68 Kantor Cabang, 171 Kantor Cabang Pembantu, dan 18 Kantor Kas. Jumlah keseluruhan KC, KCP, dan KK merupakan keempat terbanyak di Indonesia diantara bank syariah lainnya . Bank BNI Syariah Cabang Makassar merupakan salah satu diantara Kantor Cabang PT BNI Syariah yang saat ini aktif beroperasi (Fuad: 2016)

Nasabah bank BNI Syariah Cabang Makassar memiliki pola aktivitas, minat, opini dan tingkat Religiusitas yang berbeda-beda sesuai nilai dan gaya hidupnya. Berdasarkan fakta dan fenomena yang terjadi, penulis tertarik untuk melakukan suatu penelitian ilmiah yang menelisik sisi psikografis dan religiusitas nasabah bank BNI Syariah Makassar. Oleh karena itu, penelitian ini mencoba untuk mengetahui pengaruh faktor psikografis yang meliputi (1) aktivitas, (2) minat, (3) opini dan memadukannya dengan faktor religiusitas terhadap keputusan bertransaksi pada BNI Syariah Makassar.

\section{TINJAUAN TEORETIS}

\section{Teori Perilaku Konsumen}

Kotler $^{14}$ sebagaimana yang dikutip oleh Saputri ${ }^{15}$ menjelaskan bahwa perilaku konsumen adalah suatu studi tentang unit pembelian, perorangan, kelompok, atau organisasi. Unit-unit tersebut akan membentuk pasar sehingga muncul

Dinar Mas PT. Ajisaka Di Semarang)," Jurnal Administrasi Bisnis 1, no. 1 (September 30, 2012): h.12-24.

${ }^{12} \mathrm{M}$ Dharma Tuah Putra, Rossie Rossanty, and Prana Ugiana Gio, "Hubungan Antara Religiusitas dan Pengambilan Keputusan Membeli Panganan Halal Dimoderasi oleh Konsumen atas Risiko," Jurnal ilmiah Research Sains 2, no. 2 (2016): h.7-13.

${ }^{13}$ Yoiz Shofwa, "Pengaruh Kualitas Produk Dan Religiusitas Terhadap Keputusan Nasabah Produk Simpanan Pada BSM Cabang Purwokerto" (Laporan Penelitian, IAIN Purwokerto, 2015).

${ }^{14}$ Kotler and Armstrong, Prinsip-Prinsip Pemasaran (Jakarta: Erlangga, 2001).

15 Marheni Eka Saputri, "Perilaku Konsumen Terhadap Pembelian Online Produk Fashion Pada Zalora Indonesia," Jurnal Sosioteknologi 15, no. 2 (August 30, 2016): 29, doi:10.5614/sostek.itbj.2016.15.02.11. 
pasar individu atau pasar konsumen, unit pembelian kelompok, dan pasar bisnis yang dibentuk organisasi. Sedangkan menurut Schiffman dan Kanuk (1994) yang dikutip oleh Sumarwan ${ }^{16}$ menjelaskan bahwa definisi perilaku konsumen adalah perilaku yang diperlihatkan konsumen dalam mencari, membeli, menggunakan, mengevaluasi dan menghabiskan produk atau jasa yang mereka harapkan akan memuaskan kebutuhan mereka. Dari pengertian di atas dapat disimpulkan bahwa perilaku konsumen sangat erat kaitannya dengan keputusan yang akan diambil oleh konsumen dalam membeli atau menggunakan produk dan jasa yang dibutuhkannya. Timbulnya perilaku perilaku konsumen ini disebabkan oleh terdapatnya beberapa alternatif pilihan terhadap masing-masing produk yang ada di pasar, sehingga timbul juga pertimbangan dari dalam diri konsumen mana dari sekian banyak produk tersebut dapat memberikan kepuasan kepadanya.

\section{Psikografis}

Psikografis adalah identifikasi karakteristik yang menggambarkan psikologis atau kepribadian dan sikap yang mempengaruhi gaya hidup seseorang dan perilaku pembelian. Psikografis mencakup sikap, pendapat dan keyakinan tentang aspekaspek yang berkaitan dengan gaya hidup dan perilaku pembelian ${ }^{17}$. Ada dua konsep dalam Psikografis. Pertama, memberi gambaran mengenai ciri-ciri psikologis. Kedua, memandang psikografis sebagai kajian tentang aktivitas, minat dan opini. Begitu pula dengan Mowen dan Minor ${ }^{18}$ yang mengatakan bahwa psikografis adalah alat ukur yang digunakan untuk menggambarkan psikologis konsumen yang dalam praktiknya menganalisis aktivitas, minat dan opini konsumen. begitu juga dengan Sumarwan ${ }^{19}$ yang mengartikan psikografis sebagai pengukuran terhadap aktivitas, minat dan opini.

1. Aktivitas (Activity)

Engel $\mathrm{dkk}^{20}$ mengatakan bahwa Aktivitas adalah tindakan nyata seperti menonton suatu medium, berbelanja di toko, atau menceritakan kepada tetangga mengenai pelayanan yang baru. Walaupun tindakan ini biasanya diamati alasan untuk tindakan tersebut jarang untuk diukur secara langsung. Chaplin dalam A'yuni $^{21}$ mendefinisikan aktivitas sebagai segala kegiatan yang dilaksanakan

${ }^{16}$ Ujang Sumarwn, Perilaku Konsumen Teori Dan Penerapannya Dalam Pemasaran (Jakarta: Ghalia Indonesia, 2005), h.25.

17James F Engel, Blackwell Roger D, and W Minia Paul, Perilaku Konsumen Jilid 1 (Jakarta: Binarupa Aksara, 1994), 385.

${ }^{18}$ Mowen and Minor, Perilaku Konsumen, h.283.

${ }^{19}$ Sumarwn, Perilaku Konsumen Teori Dan Penerapannya Dalam Pemasaran, h.58.

${ }^{20}$ Engel, Roger D, and Paul, Perilaku Konsumen Jilid 1, h.385.

${ }^{21}$ Qurotul A'yuni, "Pengaruh Identitas, Nilai dan Aktivitas Hijabers Community Terhadap Keputusan Pembelian Jilbab pada Butik Dian Pelangi Surabaya," 
organisme secara mental ataupun fisik. Mulyono dalam A'yuni mengartikan aktivitas sebagai kegiatan atau keaktifan. Artinya, segala sesuatu yang dilakukan atau kegiatan-kegiatan yang terjadi baik fisik maupun nonfisik ${ }^{22}$.

\section{Minat (Interest)}

Interest (minat) akan semacam obyek, peristiwa atau topik adalah tingkat kegairahan yang menyertai perhatian khusus maupun terus-menerus kepadanya. Minat ialah usaha aktif menuju pelaksanaan suatu tujuan. Tujuan pada umumnya yaitu titik akhir daripada gerakan yang menuju ke sesuatu arah tetapi tujuan minat adalah melaksanakan suatu tujuan (Hidayatun, 2012: 12)

3. Opini (Opinion)

Opini menurut Prasetijo ${ }^{23}$ adalah pandangan dan perasaan konsumen dalam menanggapi isu-isu global, lokal, moral, ekonomi dan sosial. Menurut Mowen $^{24}$ opini adalah pandangan dan perasaan mengenai hal-hal sedang terjadi seperti peristiwa, topik atau trend. Opini merupakan pendapat dari setiap seseorang yang berasal dari diri mereka sendiri (Fatimah, 2013: 38).

\section{Religiusitas}

Magil yang dikutip oleh Shofwa ${ }^{25}$ menjelaskan bahwa Religiusitas merupakan sikap seseorang terhadap agama secara umum, bukan hanya kepada satu aspek atau bidangnya saja dari agama, tetapi lebih kepada sikap seseorang dalam memperlihatkan atau menunjukkan intensitas seseorang untuk menjadi orang beragama. Witya (2016: 8) menambahkan Religiusitas seringkali diidentikkan dengan keberagaman. Religiusitas juga dapat diartikan sebagai sebarapa jauh pengetahuan, seberapa kokoh keyakinan, seberapa banyak pelaksanaan ibadah dan kaidah dan seberapa dalam penghayatan atas agama yang dianutnya.

\section{Keputusan Bertransaksi}

Walker $^{26}$ mendefinisikan Pengambilan sebagai suatu proses penilaian dan pemilihan dari berbagai alternatif sesuai dengan kepentingan-kepentingan tertentu dengan menetapkan suatu pilihan yang dianggap paling

Jurnal Pendidikan Tata Niaga (JPTN) 3, no. 2 (June 15, 2015): 5, http://jurnalmahasiswa.unesa.ac.id/index.php/jptn/article/view/12077.

22 Qurotul A'yuni ...

${ }^{23}$ Ihalaw Prasetijo, Perilaku Konsumen (Yogyakarta: Andi, 2004), h.58.

${ }^{24}$ Mowen and Minor, Perilaku Konsumen.

${ }^{25}$ Shofwa, "Pengaruh Kualitas Produk Dan Religiusitas Terhadap Keputusan Nasabah Produk Simpanan Pada BSM Cabang Purwokerto."

${ }^{26}$ Boyd L Walker, Manajemen Pemasaran (Jakarta: Erlangga, 1997), 123. 
menguntungkan. Kalau ada dua atau lebih pilihan alternatif, dari dua pilihan tersebut konsumen harus memilih salah satu dari dua atau lebih alternatif yang ada, maka pemilihan salah satu dari alternatif yang ada tersebut tidak lain adalah proses pengambilan keputusan. Menurut Walker pengambilan keputusan pembelian merupakan sebuah pendekatan penyelesaian masalah pada kegiatan manusia menggunakan suatu produk guna memenuhi keinginan dan kebutuhan hidupnya.

Sedangkan Transaksi adalah suatu kegiatan yang dilakukan seseorang yang menimbulkan perubahan terhadap harta atau keuangan yang dimiliki baik itu bertambah atau berkurang. Misalnya menjual harta, membeli barang, membayar hutang serta membayar berbagai macam biaya untuk memenuhi kebutuhan hidup ${ }^{27}$. Jadi keputusan bertransaksi adalah proses konsumen melakukan penilaian terhadap berbagai alternatif pilihan yang diperlukan berdasarkan pertimbangan tertentu untuk melakukan kegiatan yang menimbulkan perubahan terhadap harta seperti menjual harta, membeli barang, membayar hutang serta berbagai macam biaya untuk memenuhi kebutuhan hidup.

Menurut Keller (2009) dalam A'yuni ${ }^{28}$ ada lima tahapan dalam pengambilan keputusan yaitu:

1. Pengenalan Masalah

Proses pembelian atau Transaksi oleh konsumen diawali sejak konsumen mengenali kebutuhan atau masalah. Kebutuhan tersebut dapat ditimbulkan oleh rangsangan internal dan eksternal. Dalam kasus pertama, salah satu kebutuhan umum seseorang (rasa lapar, haus dan seks) mencapai ambang batas tertentu dan mulai menjadi batas pendorong. Dalam kasus kedua, kebutuhan ditimbulkan oleh rangsangan eksternal. Seseorang bisa mengagumi mobil baru tetangganya atau menonton iklan televisi tentang liburan di Hawaii yang memicu pemikiran tentang melakukan suatu pembelian. ${ }^{29}$

\section{Pencarian Informasi}

Setelah konsumen yang terangsang kebutuhannya, konsumen akan terdorong untuk mencari informasi yang lebih banyak. Informasi tersebut terbagi atas dua level rangsangan. Situasi pencarian informasi yang lebih ringan

\footnotetext{
27 Bitar, "Pengertian, Bukti, Dan Jenis Transaksi Beserta Contohnya Secara Lengkap," GuruPendidikan.Com, December 1, 2016, http:/ /www.gurupendidikan.co.id/pengertian-bukti-dan-jenis-transaksi-besertacontohnya-secara-lengkap/.

28 A'yuni, "Pengaruh Identitas, Nilai dan Aktivitas Hijabers Community Terhadap Keputusan Pembelian Jilbab pada Butik Dian Pelangi Surabaya," 6. ${ }^{29}$ A'yuni, "Pengaruh Identitas, Nilai dan Aktivitas Hijabers ...., h.6
} 
dinamakan penguatan perhatian. Pada level ini orang hanya sekedar lebih peka terhadap informasi produk. Pada level selanjutnya orang mungkin lebih aktif mencari-cari bahan bacaan, menelpon teman, dan mengunjungi toko untuk mempelajari produk tertentu ${ }^{30}$.

3. Evaluasi Altenatif

Evaluasi umumnya mencerminkan keyakinan dan sikap yang memperoleh perilaku pembelian mereka. Keyakinan (believe) adalah gambaran pemikiran yang dianut seseorag tentang gambaran sesuatu. Beberapa konsep dasar membantu kita memahami proses evaluasi konsumen. Pertama, konsumen berusaha memenuhi kebutuhan. Kedua konsumen mencari manfaat tertentu dari solusi produk. Ketiga, konsumen memandang masing-masing produk sebagai sekumpul atribut dengan kemampuan yang berbeda-beda dalam memberikan manfaat yang digunakan untuk memuaskan kebutuhan itu. ${ }^{31}$

4. Keputusan Pembelian

Kotler dan Keller $^{32}$ mengatakan ada dua faktor yang memengaruhi realisasi niat menjadi sebuah keputusan pembelian. Pertama, sikap orang lain. sejauh mana sikap orang lain mengurangi alternatif yang disukai seseorang bergantung dua hal, yakni intensitas sikap negatif orang lain dan motivasi konsumen untuk menuruti keinginan orang lain. Kedua, faktor situasi yang tidak terantisipasi yang dapat muncul dan mengubah niat pembelian.

5. Perilaku pasca pembelian

Setelah pembelian atau transaksi dilakukan, konsumen akan selalu siaga terhadap informasi yang mendukung keputusannya. Konsumen akan membandingkan produk yang ia beli, dengan produk lain. Konsumen juga akan mengalami kepuasan atau ketidakpuasan tertentu. Dalam tahap ini tugas pemasar tidak berakhir saat produk dibeli, melainkan berlanjut hingga periode pasti pembelian, dan pemakaian produk pasca pembelian. ${ }^{33}$

\section{Kerangka Pikir}

Dalam kerangka pikir perlu dijelaskan secara teoritis antara variabel bebas dan variabel terikat. Berdasarkan pada uraian sebelumnya maka, kerangka pikir peneliti dalam penelitian ini adalah Keputusan Bertransaksi sebagai variabel

30 Thamrin Abdillah, Manajemen Pemasaran (Jakarta: Raja Grafindo Persada, 2016), h.127.

31 Ib Thamrin Abdillah ...

32 P Kotler and K Keller, Manajemen Pemasaran (Jakarta: Indeks, 2008), h.35.

${ }^{33}$ Abdillah, Manajemen Pemasaran, h.127. 
terikat yang dipengaruhi oleh Faktor Psikografis dan Religiusitas sebagai variabel bebas. Faktor Psikografis terbagi atas tiga faktor yaitu Aktivitas (Activity), Minat (Interest), Opini (Opinion).

Kerangka pemikiran teoretis yang disajikan di bawah ini menjelaskan bahwa ada hubungan antara variabel Aktivitas (X1), Minat (X2), Opini (X3) dan Religiusitas (X4) terhadap Keputusan Bertransaksi (Y). Maka kerangka berpikir dalam penelitian ini dapat disajikan dalam gambar berikut:

\section{Gambar 1.}

\section{Kerangka Pikir}

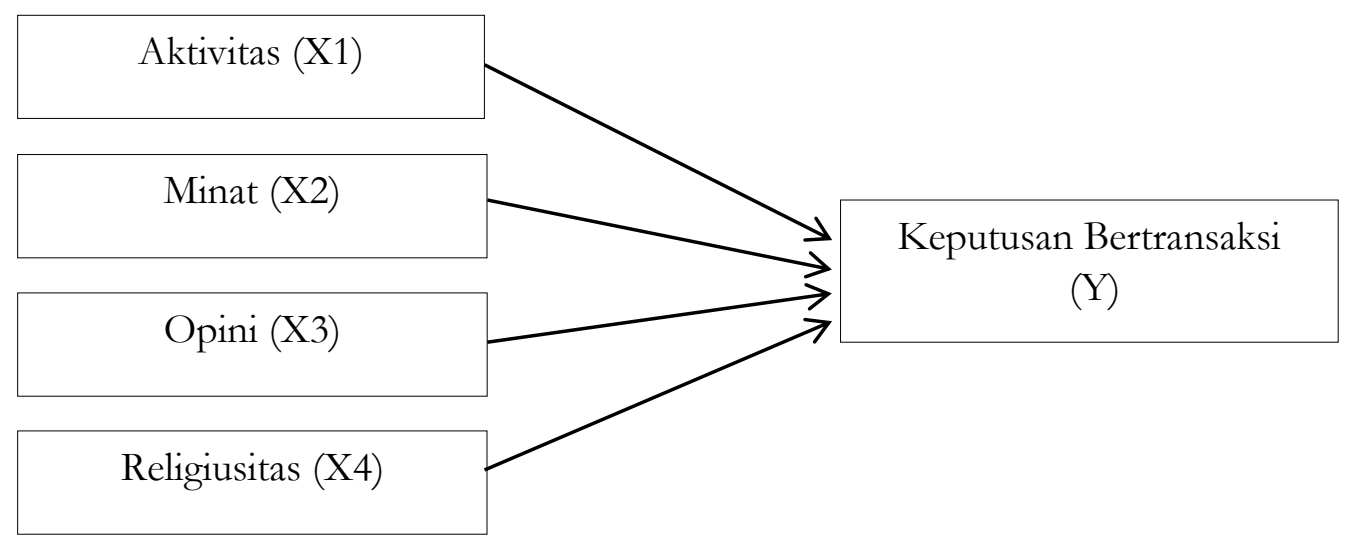

\section{METODE PENELITIAN}

Jenis penelitian yang digunakan dalam penelitian ini adalah penelitian deskriptif kuantitatif. Penelitian kuantitatif merupakan metode untuk menguji teori-teori tertentu dengan cara meneliti hubungan antar variabel ${ }^{34}$. Lokasi penelitian berada di Bank BNI Syariah Pettarani. Lokasi ini dipilih karena Bank BNI Syariah Pettarani merupakan salah satu lembaga keuangan Syariah yang terdapat di Kota Makassar.

Sumber data merupakan komponen yang terpenting dalam penelitian. Data yang dibutuhkan dalam penelitian ini dapat digolongkan menjadi dua kelompok, yaitu (1) Data Primer, data yang diperoleh dari hasil kuesioner yang disebarkan kepada responden (2) Data Sekunder, yaitu data yang tersusun secara sistematis serta merupakan hasil penelitian atau rangkuman dari dokumen-

${ }^{34}$ Juliansyah Noor, Metode Penelitian Skripsi, Tesis, Disertasi, Dan Karya Ilmiah (Jakarta: Kencana, 2010), h.38. 
dokumen perusahaan serta literatur lain seperti buku, majalah, surat kabar, makalah, dan situs web (Hasan, 2002: 82)

Populasi pada penelitian ini adalah nasabah bank BNI Syariah Kantor Cabang Makassar. Penentuan sampel penelitian ini bersifat tidak acak (nonprobality sampling) dimana anggota populasi tidak mempunyai kesempatan yang sama untuk dipilih sebagai sampel. Dalam penelitian ini, metode pengambilan sampel yaitu dengan accidental sampling. Accidental sampling adalah pemilihan dimana individu yang dipilih adalah individu yang kebetulan dijumpai di lokasi penelitian (Winarsunu, 2006: 11). Oleh karena jumlah populasi yang tidak diketahui maka pengambilan jumlah sampel dilakukan dengan menggunakan metode Roscoe (1975) yang mengatakan bahwa untuk penelitian multivariabel, ukuran sampel harus (10 kali) lebih besar dari jumlah variabel (Suryani dan Hendrayadi, 2015: 193). Jumlah variabel pada penelitian ini adalah 5 variabel, maka $5 \times 10=50$ sampel. Pada penelitian ini penulis menetapkan 70 sampel.

Agar variabel yang tercakup dalam penelitian dapat memberikan arti yang sama dan dapat diukur, maka dibuat definisi operasional dari masing-masing variabel. Variabel bebas $(\mathrm{X})$ dalam penelitian ini adalah Psikografis yang terdiri atas Aktivitas (X1), Minat (X2), Opini (X3). Selain variabel Psikografis, penulis juga menambahkan variabel Religiusitas (X4) dalam perspektif Islam. Berikut ini definisi operasional masing-masing variabel

1. Aktivitas (activity) adalah Tindakan nyata, apa yang dikerjakan seseorang, produk apa yang dibeli atau digunakan, kegiatan apa yang mereka lakukan untuk mengisi waktu luang atau menceritakan kepada orang lain mengenai pelayanan atau produk tertentu. Aktivitas juga dapat berupa pekerjaan, hobby dan kejadian sosial ${ }^{35}$. Adapun indikatornya sebagai berikut:
a. Melakukan transaksi di bank syariah
b. Menggunakan Produk bank syariah
c. Menggunakan produk untuk menunjang pekerjaan
d. Menggunakan produk untuk menunjang hobi
e. Menceritakan kepada orang lain tentang produk dan pelayanan bank syariah

2. Minat (Interest) adalah kesukaan, ketertarikan dan prioritas dalam hidup seseorang. Minat juga berarti usaha aktif menuju pelaksanaan suatu Tujuan, seperti mencari informasi mengenai produk barang atau jasa yang diinginkan ${ }^{36}$. Adapun indikatornya sebagai berikut:

a. Tertarik menggunakan produk bank syariah

b. Menyukai produk bank syariah

${ }^{35}$ Engel, Roger D, and Paul, Perilaku Konsumen Jilid 1, h.358.

${ }^{36}$ Prasetijo, Perilaku Konsumen, h.58. 
c. Memprioritaskan produk bank syariah

d. Mencari Informasi mengenai produk bank syariah

3. Opini (opinion) adalah Pandangan dan perasaan seseorang dalam menanggapi isu-isu global, ekonomi dan sosial. Opini merupakan pendapat seseorang yang berasal dari seseorang yang berasal dari pribadi mereka sendiri ${ }^{3}$. Adapun indikatornya sebagai berikut:

a. Produk bank syariah sudah sesuai dengan prinsip syariah

b. Aktivitas dan kegiatan operasional bank syariah sudah sesuai dengan prinsip syariah

c. Produk bank syariah berbeda dengan produk bank konvensional

d. Bertransaksi di bank syariah lebih aman dan menguntungkan

4. Religiusitas adalah tingkat di mana seseorang mempunyai komitmen atau setia kepada agamanya. Religiusitas diartikan seberapa kokoh keyakinan, seberapa banyak pelaksanaan perintah / ibadah, seberapa jauh seseorang menjauhi larangan, sebarapa tinggi pengetahuan, dan seberapa dalam penghayatan seseeorang dalam melakukan pengamalan agama yang dianutnya ${ }^{38}$. Adapun indikatornya

a. Meyakini Allah dan menuhankannya

b. Menjalankan perintah Allah dan menjauhi larangannya

c. Mengetahui hukum riba dan bunga bank

d. Memahami kaidah umum ekonomi Islam dan perbankan syariah

e. Menjalankan norma-norma Islam dalam kehidupan sehari-hari

Indikator variabel-variabel ini diukur dengan skala Likert yaitu mengukur sikap dengan mengatakan setuju atau tidak setuju terhadap pernyataan yang diajukan dengan skor 5 (SS = Sangat Setuju), skor 4 (S = Setuju), skor $3(\mathrm{~N}=$ Netral), skor 2 (TS = Tidak Setuju), skor 1 (STS = Sangat Tidak Setuju)

Variabel bebas dalam penelitian ini adalah keputusan bertransaksi (Y). Keputusan transaksi adalah proses dimana seseorang melakukan penilaian terhadap berbagai alternatif pilihan dan memilih yang diperlukan berdasarkan pertimbangan tertentu. Proses tersebut meliputi Pengenalan masalah, penacarian informasi, evaluasi, keputusan final, dan perilaku setelah pembelian atau transaksi. Adapun indikatornya sebagai berikut:

1. Melakukan transaksi di bank syariah karena kebutuhan

2. Mengunjungi kantor cabang bank syariah atau situs resmi untuk mendapatkan informasi

3. Biaya admin produk bank syariah sesuai dengan kualitas produk

${ }^{37}$ Prasetijo, Perilaku Konsumen ...,

38 Shofwa, "Pengaruh Kualitas Produk Dan Religiusitas Terhadap Keputusan Nasabah Produk Simpanan Pada BSM Cabang Purwokerto,” h.14. 
4. Produk bank syariah lebih baik dibanding bank konvensional

5. Memutuskan untuk menggunakan produk bank syariah karena prinsip syariah yang diterapkan

6. Merasa puas dengan pelayanan dan kualitas produk bank syariah

\section{HASIL DAN PEMBAHASAN}

\section{Gambaran Umum Lokasi Penelitian}

BNI Syariah Makassar dibuka pada tahun 2001 bersama dengan kantor cabang lain di Jakarta Timur, Jakarta Selatan, Bandung dan Padang. Keputusan BNI untuk membuka divisi usaha syariah merupakan jawaban terhadap tuntutan pasar. Hal ini ditunjang dengan landasan hukum yang jelas dan kondisi yang memungkinkan pengalaman BNI beroperasi sebagai bank umum konvensional selama lebih 50 tahun. Selain itu, didukung pula dengan orang yang kapabel dan berkompeten di bidang syariah Islam yang duduk sebagai Dewan Pengawas Syariah (DPS).

Selain adanya faktor legal yang mendukung, pertimbangan lain bagi Bank Negara Indonesia untuk memberikan pelayanan syariah karena adanya peluang bisnis yang besar. Pertama, mayoritas penduduk Indonesia adalah pemeluk agama Islam yang tentunya memiliki keinginan untuk menjalankan syariah dengan sebaik-baiknya. Kedua, dengan prinsip bagi hasil yang merupakan landasan utama perbankan syariah, diharapkan Bank Negara Indonesia dapat memaksimalkan return sehingga dapat meningkatkan kinerja BNI Syariah secara keseluruhan. Namun demikian, dalam kegiatan penghimpunan dana, pembiayaan maupun sistem akuntansinya sama sekali terpisah dengan BNI Konvensional yang melakukan kegiatan perbankan umum. Hal ini dilakukan untuk memenuhi ketentuan yang berlaku dan menjaga agar kegiatan usaha BNI syariah tidak melanggar prinsip-prinsip syariah Islam.

\section{Hasil Penelitian}

\section{Analisis Deskriptif}

Statistik deskriptif memberikan gambaran atau deskripsi suatu data yang dilihat dari nilai rata-rata (mean), standar deviasi, minimum dan maximum. Adapun hasil output SPSS berdasarkan penelitian yang telah dilakukan sebagai berikut:

\section{Tabel 1.}

Deskriptif Statistik

\begin{tabular}{llllll}
\hline Variabel & N & Minimum & Maximum & Mean & Std. \\
\hline
\end{tabular}


Deviation

\begin{tabular}{llllll}
\hline Aktivitas & 56 & 16 & 24 & 20.91 & 2.021 \\
Minat & 56 & 13 & 19 & 16.30 & 1.683 \\
Opini & 56 & 12 & 19 & 16.59 & 1.703 \\
Religiusitas & 56 & 17 & 25 & 21.82 & 2.037 \\
Keputusan & 56 & 18 & 28 & 24.20 & 2.430 \\
Bertransaksi & & & & & \\
\hline Valid N & 56 & & & & \\
(Listwise) & & & &
\end{tabular}

Sumber : Data Primer yang diolah, 2017

Berdasarkan tabel 1, Deskriptif statistik menunjukkan bahwa untuk variabel aktivitas (X1) dari seluruh jawaban responden lebih banyak yang memberikan jawaban setuju dan sangat setuju dengan nilai rata-rata (mean) sebesar 20.91\% dengan standar deviasi sebesar 2.021. Variabel minat (X2) jawaban seluruh responden cenderung memilih setuju dan sangat setuju, namun tak sedikit yang memilih netral, dengan nilai rata-rata (mean) $16.30 \%$ yang mendekati angka maksimum sebesar 19 dengan standar deviasi 1.683.

Begitu juga dengan variabel opini (X3) dari seluruh total responden memberikan jawaban setuju dan sangat setuju dengan nilai rata-rata (mean) sebesar $16.59 \%$ yang mendekati angka maksimum 19 dengan standar deviasi 1.703. Variabel Religiusitas (X4) dari seluruh jumlah responden lebih banyak memberikan jawaban sangat setuju dengan nilai rata-rata $21.82 \%$ yang mendekati angka maksimum 25 dengan standar deviasi 2.037.

Dengan demikian dapat disimpulkan bahwa dari seluruh variabel yang digunakan dalam penelitian, nilai rata-rata tertinggi (mean) berada pada variabel Religiusitas (X4) yakni $21.82 \%$ dan yang terendah yaitu variabel minat (X2) dengan nilai rata-rata (mean) sebesar $16.30 \%$. Standar deviasi tertinggi berada pada variabel Religiusitas (X4) dengan nilai rata-rata tertinggi tertinggi dari seluruh variabel penelitian ini. Hal ini berarti variabel Religiusitas memiliki keragaman sampel yang paling tinggi dan memiliki rentang variasi data yang tinggi.

\section{Uji Validitas}

Uji Validitas digunakan untuk mengukur sah/valid atau tidaknya suatu pernyataan pada kuesioner. Suatu kuesioner dikatakan valid jika pernyataan pada kuesioner mampu mengungkapkan sesuatu yang akan diukur. Jika $r$ hitung lebih besar dari $\mathrm{r}$ tabel dan nilai positif maka butir pernyataan atau indikator tersebut dinyatakan valid. Jika $r$ hitung $>$ dari $r$ tabel (pada taraf signifikasi 0.05 ) maka 
pernyataan tersebut dinyatakan valid ${ }^{39}$. Pengujian validitas selengkapnya dapat dilihat sebagai berikut:

\section{Tabel 2.}

Hasil Uji Validitas

Variabel Psikografis Aktivitas

\begin{tabular}{ccccc}
\hline No. & Item & r Hitung & r Tabel & Keterangan \\
\hline 1 & $\mathrm{X} 1.1$ & 0.558 & 0.266 & Valid \\
2 & $\mathrm{X} 1.2$ & 0.619 & 0.266 & Valid \\
3 & $\mathrm{X} 1.3$ & 0.681 & 0.266 & Valid \\
4 & $\mathrm{X} 1.4$ & 0.518 & 0.266 & Valid \\
5 & $\mathrm{X} 1.5$ & 0.658 & 0.266 & Valid \\
\hline
\end{tabular}

Sumber: Data Primer yang diolah, 2017

Berdasarkan tabel 2, terlihat bahwa masing-masing pernyataan variabel psikografis aktivitas (X1) menunjukkan hasil signifikan dan menunjukkan bahwa $r$ hitung lebih besar dari pada $\mathrm{r}$ tabel, sehingga dapat dikatakan bahwa item variabel aktivitas (X1) pada penelitian ini adalah valid untuk dipergunakan sebagai instrumen, atau pernyataan yang diajukan dapat digunakan untuk mengukur variabel yang diteliti.

Tabel 3.

Hasil Uji Validitas

Variabel Psikografis Minat

\begin{tabular}{ccccc}
\hline No. & Item & r Hitung & r Tabel & Keterangan \\
\hline 1 & X2.1 & 0.749 & 0.266 & Valid \\
2 & X2.2 & 0.730 & 0.266 & Valid \\
3 & X2.3 & 0.577 & 0.266 & Valid \\
4 & X2.4 & 0.545 & 0.266 & Valid \\
\hline
\end{tabular}

Sumber : Data Primer yang diolah, 2017

Berdasarkan tabel 3. terlihat bahwa masing-masing pernyataan variabel psikografis minat (X2) menunjukkan hasil signifikan dan menunjukkan bahwa $\mathrm{r}$ hitung lebih besar dari pada $\mathrm{r}$ tabel, sehingga dapat dikatakan bahwa item variabel aktivitas (X2) pada penelitian ini adalah Valid untuk dipergunakan sebagai instrumen, atau pernyataan yang diajukan dapat digunakan untuk mengukur variabel yang diteliti.

Tabel 4.

Hasil Uji Validitas

39 Imam Ghozali, Aplikasi Analisis Multvariate Dengan Program SPSS (Semarang: Badan Penerbt Undip, 2006), 52. 
60 |Al-Falah: Journal of Islamic Economics, Vol.3, No.1, 2018

Variabel Psikografis Opini

\begin{tabular}{ccccc}
\hline No. & Item & r Hitung & r Tabel & Keterangan \\
\hline 1 & X3.1 & 0.825 & 0.266 & Valid \\
2 & X3.2 & 0.852 & 0.266 & Valid \\
3 & X3.3 & 0.556 & 0.266 & Valid \\
4 & X3.4 & 0.410 & 0.266 & Valid \\
\hline
\end{tabular}

Sumber : Data Primer yang diolah, 2017

Berdasarkan tabel 4. terlihat bahwa masing-masing pernyataan variabel opini (X3) menunjukkan hasil signifikan dan menunjukkan bahwa $\mathrm{r}$ hitung lebih besar dari pada $r$ tabel, sehingga dapat dikatakan bahwa item variabel opini (X3) pada penelitian ini adalah valid untuk dipergunakan sebagai instrumen, atau pernyataan yang diajukan dapat digunakan untuk mengukur variabel yang diteliti.

Tabel 5.

Hasil Uji Validitas

Variabel Religiusitas

\begin{tabular}{ccccc}
\hline No. & Item & r Hitung & r Tabel & Keterangan \\
\hline 1 & X4.1 & 0.599 & 0.266 & Valid \\
2 & X4.2 & 0.766 & 0.266 & Valid \\
3 & X4.3 & 0.737 & 0.266 & Valid \\
4 & X4.4 & 0.684 & 0.266 & Valid \\
5 & X4.5 & 0.652 & 0.266 & Valid \\
\hline
\end{tabular}

Sumber: Data Primer yang diolah, 2017

Berdasarkan tabel 5. terlihat bahwa masing-masing pernyataan variabel Religiusitas (X4) menunjukkan hasil signifikan dan menunjukkan bahwa $\mathrm{r}$ hitung lebih besar dari pada $\mathrm{r}$ tabel, sehingga dapat dikatakan bahwa item variabel Religiusitas (X4) pada penelitian ini adalah valid untuk dipergunakan sebagai instrumen, atau pernyataan yang diajukan dapat digunakan untuk mengukur variabel yang diteliti.

Tabel 6.

Hasil Uji Validitas

Variabel Psikografis Keputusan Bertransaksi

\begin{tabular}{ccccc}
\hline No. & Item & r Hitung & r Tabel & Keterangan \\
\hline 1 & Y1 & 0.602 & 0.266 & Valid \\
2 & Y2 & 0.583 & 0.266 & Valid \\
3 & Y3 & 0.561 & 0.266 & Valid \\
4 & Y4 & 0.629 & 0.266 & Valid \\
5 & Y5 & 0.665 & 0.266 & Valid \\
\hline
\end{tabular}




\begin{tabular}{ccccc}
\hline 6 & Y6 & 0.540 & 0.266 & Valid \\
\hline \multicolumn{4}{c}{ Sumber : Data Primer yang diolah, 2017 }
\end{tabular}

Berdasarkan tabel 6. terlihat bahwa masing-masing pernyataan variabel Keputusan bertransaksi $(\mathrm{Y})$ menunjukkan hasil signifikan dan menunjukkan bahwa $r$ hitung lebih besar dari pada $r$ tabel, sehingga dapat dikatakan bahwa item variabel keputusan bertransaksi $(\mathrm{Y})$ pada penelitian ini adalah valid untuk dipergunakan sebagai instrumen, atau pernyataan yang diajukan dapat digunakan untuk mengukur variabel yang diteliti.

\section{Uji Reliabilitas}

Reliabilitas adalah alat untuk mengukur suatu kuesioner yang merupakan indikator dari variabel atau konstruk. Suatu kuesioner dikatakan reliabel atau handal jika jawaban seseorang terhadap pertanyaan konsisten atau stabil dari waktu ke waktu. SPSS memberikan fasilitas untuk mengukur reliabilitas dengan Cronbach alpha $(\alpha)$. Menurut Kriteria Nunnally (1994) suatu variabel atau konstruk dikatakan reliabel jika memberikan nilai $(\alpha) 0,70^{40}$. Hasil pengujian reliabilitas untuk masing-masing variabel adalah sebagai berikut :

Tabel 7.

Hasil Uji Reliabilitas

\begin{tabular}{llccc}
\hline No & \multicolumn{1}{c}{ Variabel } & $\begin{array}{c}\text { Cronbachs } \\
\text { Alpha }\end{array}$ & N Of Items & Keterangan \\
\hline 1 & Aktivitas & 0.546 & 5 & Reliabel \\
2 & Minat & 0.530 & 4 & Reliabel \\
3 & Opini & 0.598 & 4 & Reliabel \\
4 & Religiusitas & 0.722 & 5 & Reliabel \\
5 & Keputusan & 0.633 & 6 & Reliabel \\
& Bertransaksi & & & \\
\hline
\end{tabular}

Sumber: Data Primer yang diolah, 2017

Berdasarkan hasil uji reliabilitas yang tertera pada tabel 7. menunjukkan bahwa semua variabel memiliki koefisien alpha yang cukup besar di atas 0,70 sehingga dapat dikatakan semua konsep pengukur masing-masing variabel dari kuesioner adalah reliabel sehingga untuk selanjutnya item-item pada masingmasing konsep variabel tersebut layak untuk digunakan sebagai alat ukur.

\section{Uji Asumsi Klasik}

${ }^{40}$ Imam Ghozali, Aplikasi Analisis Multvariate Dengan Program SPSS , h.51. 
Sebelum dilakukan uji hipotesis, data yang digunakan terlebih dahulu dipastikan telah memenuhi asumsi klasik, yakni uji Multikolinearitas, Uji Heteroskedastisitas, dan Uji Normalitas.

\section{Tabel 8.}

\section{Hasil Uji Multikolinearitas}

\section{Coefficients $^{\mathrm{a}}$}

\begin{tabular}{llll} 
Model & \multicolumn{2}{c}{ Collinearity } \\
\cline { 3 - 4 } & & Statistics \\
\cline { 3 - 4 } & & & \\
\hline 1 & Toleranc & VIF \\
& Aktivitas & .583 & 1.715 \\
& Minat & .721 & 1.388 \\
& Opini & .607 & 1.647 \\
& Religiusit & .726 & 1.377
\end{tabular}

\begin{tabular}{l}
\hline a. Dependent Variabel: Keputusan \\
Bertransaksi
\end{tabular}

Sumber: Data Primer yang diolah, 2017

Tabel 8. menunjukkan bahwa hasil uji multikolinearitas pada model regresi tidak terjadi gejala multikolinearitas. Hal ini dapat dilihat dari nilai VIF pada semua variabel bebas tidak lebih dari 10,00 dan nilai tolerance lebih dari 0,01 . Model regresi yang baik adalah tidak terjadinya gejala multikolinearitas.

Tabel 9.

Hasil Uji Heteroskedastisitas Glejser

\begin{tabular}{lllll}
\hline Model & \multicolumn{3}{c}{ Coefficients $^{\mathbf{a}}$} & Unstandardized \\
Coefficients & $\begin{array}{c}\text { Standardi } \\
\text { zed } \\
\text { Coefficie }\end{array}$ & T & Sig. \\
\hline
\end{tabular}




\begin{tabular}{llrrrr}
\hline & \multicolumn{5}{c}{ nts } \\
\cline { 2 - 4 } & \multicolumn{1}{c}{ B } & Std. Error & \multicolumn{1}{c}{ Beta } & \\
\hline 1 (Constant) & 1.922 & 1.819 & & & .296 \\
Aktivitas & .049 & .087 & .101 & .556 & .581 \\
Minat & -.004 & .094 & -.007 & -.042 & .967 \\
Opini & -.026 & .102 & -.046 & -.256 & .799 \\
Religiusitas & -.051 & .078 & -.108 & -.658 & .513 \\
\hline a. Dependent Variabel: Keputusan Bertransaksi & & & \\
\hline
\end{tabular}

Sumber: Data Primer yang diolah, 2017

Berdasarkan pada tabel 9. menunjukkan dengan jelas bahwa seluruh variabel bebas secara signifikan mempengaruhi variabel terikat. Hal ini terlihat dari probabilitas signifikannya di atas tingkat kepercayaan 0,05 , sehingga dapat disimpulkan bahwa pada model regresi tidak terjadi heteroskedastisitas.

Tabel 10.

Hasil Uji Normalitas

\begin{tabular}{llr}
\hline & One-Sample Kolmogorov-Smirnov Test & $\begin{array}{c}\text { Unstandard } \\
\text { ized } \\
\text { Residual }\end{array}$ \\
\hline $\mathrm{N}$ & & 56 \\
Normal Parameters ${ }^{\mathrm{a}, \mathrm{b}}$ & Mean & .0000000 \\
& Std. Deviation & 1.65219384 \\
Most Extreme & Absolute & .076 \\
Differences & Positive & .056 \\
& Negative & -.076 \\
Test Statistic & & .076 \\
Asymp. Sig. (2-tailed) & & $.200^{\mathrm{c}, \mathrm{d}}$ \\
\hline
\end{tabular}

a. Test distribution is Normal.

b. Calculated from data.

c. Lilliefors Significance Correction.

$\mathrm{d}$. This is a lower bound of the true significance.

Berdasarkan tabel 10. dapat dilihat hasil uji normalitas Kolmogorov smirnov menunjukkan nilai signifikasi model regresi berada di atas tingkat kepercayaan 5\% atau 0,05 yaitu sebesar 0,200. Dapat disimpulkan bahwa data pada penelitian terdistribusi normal.

\section{Hasil Analisis Regresi Berganda}


Tabel 11.

Hasil Uji Determinasi

\begin{tabular}{lcccc}
\hline & \multicolumn{4}{c}{ Model Summary $^{\text {b }}$} \\
Mod & $\mathrm{R}$ & $\mathrm{R}$ & Adjusted R & Std. Error \\
$\mathrm{el}$ & & Square & Square & of the \\
& & & & Estimate \\
\hline
\end{tabular}

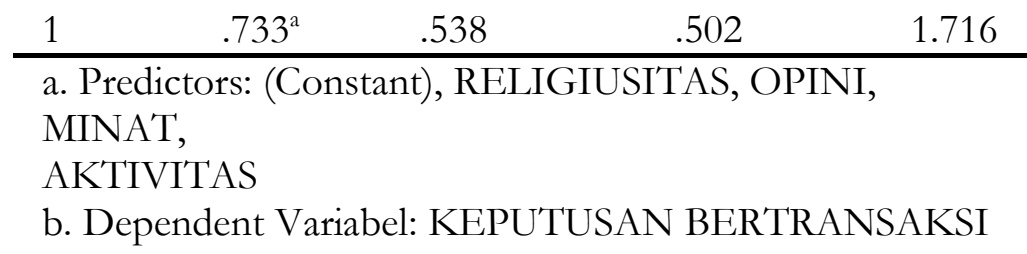

Berdasarkan tabel 11. besarnya Adjusted R Square adalah 0.502, hal ini berarti $50,2 \%$ variabel keputusan bertransaksi dapat dijelaskan dari variabel psikografis aktivitas, psikografis minat, psikografis opini dan Religiusitas. Sedangkan sisanya $(100 \%-50,2 \%=49,8 \%)$ dijelaskan oleh sebab-sebab lain di luar model.

a. Hasil Uji Signifikasi Simultan (Uji F)

\section{Tabel 12.}

Hasil Uji F

\begin{tabular}{|c|c|c|c|c|c|c|}
\hline \multicolumn{7}{|c|}{ ANOVA $^{a}$} \\
\hline \multicolumn{2}{|c|}{ Model } & \multirow{2}{*}{$\begin{array}{l}\begin{array}{c}\text { Sum of } \\
\text { Squares }\end{array} \\
174.703\end{array}$} & \multirow{2}{*}{$\frac{\text { Df }}{4}$} & \multirow{2}{*}{$\begin{array}{c}\begin{array}{c}\text { Mean } \\
\text { Square }\end{array} \\
43.676\end{array}$} & \multirow{2}{*}{$\begin{array}{c}\mathrm{F} \\
14.836\end{array}$} & \multirow{2}{*}{$\begin{array}{l}\text { Sig. } \\
\frac{.000^{\mathrm{b}}}{}\end{array}$} \\
\hline \multirow[t]{3}{*}{1} & Regression & & & & & \\
\hline & Residual & 150.136 & 51 & 2.944 & & \\
\hline & Total & 324.839 & 55 & & & \\
\hline
\end{tabular}

a. Dependent Variabel: KEPUTUSAN BERTRANSAKSI

b. Predictors: (Constant), RELIGIUSITAS, OPINI, MINAT, AKTIVITAS

Sumber: Data Primer yang diolah, 2017

Berdasarkan uji ANOVA atau Uji F pada tabel 12. dapat dilihat bahwa nilai $\mathrm{F}$ hitung sebesar 14.836 dengan probablilitas 0.000 , karena probabilitas yang dihasilkan jauh lebih kecil dari 0,05 dan niali $\mathrm{F}$ hitung lebih besar dari $\mathrm{F}$ Tabel $(2,55)$ maka dapat disimpulkan bahwa variabel aktivitas, minat, opini dan Religiusitas sama-sama berpengaruh terhadap keputusan bertransaksi nasabah, sehingga setiap variabel dapat diuji parsial (Uji t).

b. Hasil Uji Signifikasi Parsial (Uji t) 
Tabel 13.

Hasil Uji t

\begin{tabular}{|c|c|c|c|c|c|}
\hline \multirow{3}{*}{ Model } & \multicolumn{3}{|c|}{ Coefficients $^{a}$} & \multirow{3}{*}{$\mathrm{T}$} & \multirow{3}{*}{ Sig. } \\
\hline & \multicolumn{2}{|c|}{$\begin{array}{c}\text { Unstandardized } \\
\text { Coefficients }\end{array}$} & \multirow{2}{*}{$\begin{array}{l}\text { Standardized } \\
\text { Coefficients } \\
\text { Beta }\end{array}$} & & \\
\hline & $\bar{B}$ & $\begin{array}{l}\text { Std. } \\
\text { Error }\end{array}$ & & & \\
\hline 1 (Constant) & 1.763 & 3.123 & & .565 & .575 \\
\hline AKTIVITAS & .379 & .150 & .316 & 2.531 & .015 \\
\hline MINAT & -.020 & .162 & -.014 & -.123 & .902 \\
\hline OPINI & .523 & .174 & .367 & 3.003 & .004 \\
\hline RELIGIUSITAS & .281 & .133 & .236 & 2.111 & .040 \\
\hline
\end{tabular}

Berdasarkan tabel 13. hasil perhitungan variabel bebas dapat disusun dalam suatu model berikut:

$$
\mathrm{Y}=1.763+0.379 \mathrm{X} 1-0.020 \mathrm{X} 2+0.523 \mathrm{X} 3+0.281 \mathrm{X} 4
$$

Keterangan:

$$
\begin{array}{ll}
\mathrm{Y} & =\text { Keputusan bertransaksi } \\
\mathrm{X} 1 & =\text { Variabel bebas yaitu Psikografis Aktivitas } \\
\mathrm{X} 2 & =\text { Variabel bebas yaitu Psikografis Minat } \\
\mathrm{X} 3 & =\text { Variabel bebas yaitu Psikografis Opini } \\
\mathrm{X} 4 & =\text { Variabel bebas yaitu Relgiusitas } \\
\alpha & =\text { Konstanta }
\end{array}
$$

Hasil dari analisis tersebut dapat diinterpretasikan sebagai berikut :

1) Nilai konstanta persamaan di atas sebesar 1.763. angka tersebut menunjukkan bahwa jika X1 (Aktivitas), X2 (Minat), X3 (Opini), dan X4 (Religiusitas) konstan atau $\mathrm{X}=0$ maka Keputusan Bertransaksi sebesar 1.763

2) X1 (Aktivitas), menunjukkan nilai koefisien sebesar 0.379. Hal ini berarti bahwa jika terjadi peningkatan penyebab aktivitas sebesar 1\% terhadap Nasabah maka keputusan bertransaksi juga akan mengalami peningkatan 
sebesar variabel pengalinya 0.379 dengan asumsi variabel lainnya dianggap konstan

3) X2 (Minat), menunjukkan nilai koefisien sebesar -0,020. Hal ini berarti bahwa jika terjadi peningkatan penyebab minat sebesar 1\% terhadap nasabah maka keputusan bertransaksi tidak akan mengalami peningkatan sebesar variabel pengalinya dengan asumsi variabel lainnya dianggap konstan.

4) $\mathrm{X} 3$ (Opini), menunjukkan nilai koefisien sebesar 0.523. Hal ini berarti bahwa jika terjadi peningkatan penyebab opini sebesar 1\% terhadap Nasabah maka keputusan bertransaksi juga akan mengalami peningkatan sebesar variabel pengalinya 0.523 dengan asumsi variabel lainnya dianggap konstan

5) X4 (Religiusitas), menunjukkan nilai koefisien sebesar 0.281. Hal ini berarti bahwa jika terjadi peningkatan penyebab aktivitas sebbesar 1\% terhadap Nasabah maka keputusan bertransaksi juga akan mengalami peningkatan sebesar variabel pengalinya 0.281 dengan asumsi variabel lainnya dianggap konstan.

\section{Pengaruh Psikografis Aktivitas terhadap Keputusan bertransaksi pada bank BNI Syariah Makassar}

Berdasarkan hasil analisis menunjukkan bahwa variabel Psikografis Aktivitas berpengaruh terhadap keputusan bertransaksi pada bank BNI Syariah Makassar. Hal ini berarti hipotesis pertama yang menyatakan Psikografis aktivitas berpengaruh terhadap keputusan bertransaksi pada bank BNI Syariah Makassar diterima. Hal ini berarti aktivitas transaksi keuangan sudah menjadi hal yang biasa dilakukan oleh masyarakat. Produk-produk bank syariah sangat beragam sehingga dapat menunjang aktivitas nasabah. Bank BNI Syariah telah bekerja sama dengan beberapa instansi/perusahaan sehingga dapat menjadi media bagi para pegawai/karyawan dalam menunjang pekerjaan seperti menerima gaji. Bank BNI Syariah juga memiliki produk-produk yang dapat menunjang hobbi nasabah, seperti kartu debit dan credit yang dapat menunjang nasabah yang memiliki hobbi belanja online dan belanja dengan transaksi non tunai secara syariah. Kartu debit/credit juga memiliki logo atm bersama dan master card sehingga dapat digunakan di dalam dan luar negeri, tentu sangat mendukung nasabah yang memiliki hobbi berwisata. 
Penelitian ini mendukung hasil penelitian yang dilakukan Roza (2014) ${ }^{41}$ yang mengatakan bahwa aktivitas berpengaruh terhadap keputusan konsumen memilih Tupperware. Hal ini sesuai dengan teori aktivitas yang dikemukakan Mowen dan Minor (2015) ${ }^{42}$ bahwa aktivitas adalah tindakan nyata, apa yang dilakukan seseorang, apa yang mereka beli dan bagaimana mereka menghabiskan waktu luang. Apa yang biasa dilakukan oleh seseorang baik pekerjaan atau hobi akan mempengaruhi mereka dalam pengambilan keputusan pembelian barang atau jasa. Jika produk barang atau jasa dari seorang produsen semakin dapat menunjang aktivitas konsumen, seperti pekerjaan dan hobbi konsumen, maka akan berdampak pada keputusan pembelian terhadap barang atau jasa.

\section{Pengaruh Psikografis Minat terhadap Keputusan Bertransaksi pada bank BNI Syariah Makassar}

Berdasarkan hasil analisis menunjukkan bahwa variabel Psikografis minat tidak berpengaruh terhadap keputusan bertransaksi pada bank BNI Syariah Makassar. Hal ini berarti hipotesis kedua yang menyatakan Psikografis minat berpengaruh terhadap keputusan bertransaksi pada bank BNI Syariah Makassar ditolak. Ini berarti nasabah bank syariah menggunakan produk bank syariah bukan karena minat, tetapi karena faktor-faktor lain, seperti karena terpaksa, mengikuti aturan kerja, aturan agama, dan lain-lain. Apalagi masih banyak nasabah yang ternyata memiliki rekening ganda, memiliki rekening baik di bank syariah maupun di bank konvensional.

Penelitian ini mendukung hasil penelitian Listyorini (2012) ${ }^{43}$ yang menemukan bahwa minat tidak berpengaruh signifikan terhadap keputusan pembelian rumah sehat sederhana. Hal ini sesuai dengan teori minat yang dikemukakan oleh Mowen dan Minor (2002) ${ }^{44}$ yang mengatakan bahwa minat adalah kesukaan, kegemaran dan prioritas konsumen terhadap sesuatu. Seseorang akan melakukan pembelian terhadap sesuatu yang disukainya, namun terkadang konsumen melakukan pembelian tanpa harus terlebih dahulu membangun perasaan suka terhadap produk tersebut. Menurut penulis, salah satu penyebab minat tidak berpengaruh adalah kurangnya penggunaan media informasi untuk mengenalkan produk kepada masyarakat. Hal ini juga terjadi

41 Roza, "Analisis Pengaruh Gaya Hidup Terhadap Keputusan Konsumen Memilih Eco Product (Studi Kasus Pada Konsumen Tupperware Di Kota Jambi) Jurnal Penelitian Universitas Jambi: Seri Humaniora."

42 Mowen and Minor, Perilaku Konsumen.

${ }^{43}$ Listyorini, “Analisis Faktor-Faktor Gaya Hidup Dan Pengaruhnya Terhadap Pembelian Rumah Sehat Sederhana (Studi Pada Pelanggan Perumahan Puri Dinar Mas PT. Ajisaka Di Semarang)."

${ }^{44}$ Mowen and Minor, Perilaku Konsumen. 
pada BNI Syariah Makassar yang tidak memanfaatkan media informasi seperti koran, televisi atau papan iklan untuk menarik minat nasabah. Ditambah lagi keberadaan bank konvensional yang telah tersebar dimana-mana hingga ke daerah, seperti BNI Konvensional membuat masyarakat masih lebih menyukai dan memprioritaskan Bank konvensional.

\section{Pengaruh Psikografis Opini terhadap Keputusan Bertransaksi pada bank BNI Syariah Makassar}

Berdasarkan hasil analisis menunjukkan bahwa variabel Psikografis Opini berpengaruh terhadap keputusan bertransaksi pada bank BNI Syariah Makassar. Hal ini berarti hipotesis ketiga yang menyatakan bahwa Psikografis Opini berpengaruh terhadap keputusan bertransaksi pada BNI Syariah Makassar diterima.Ini berarti nasabah yang memutuskan untuk bertransaksi pada BNI Syariah Makassar adalah nasabah yang memiliki persepsi positif terhadap BNI Syariah Makassar. Mereka menganggap bahwa label Syariah pada nama bank tersebut bukan hanya sekadar label. Produk dan kegiatan operasional sudah sesuai dengan prinsip syariah. Produk dan kegiatan operasional sudah berbeda dengan bank konvensional, dan mereka menganggap bahwa bertransaksi di bank BNI Syariah lebih aman dan menguntungkan, sehingga konsumen memilih bertransaksi di BNI Syariah Makassar.

Penelitian ini mendukung hasil penelitian Ekasari (2015) ${ }^{45}$ yang mengatakan bahwa Opini berpengaruh terhadap keputusan pembelian laptop Apple. Hal ini sesuai dengan teori opini yang dikemukakan oleh Setiadi (2015) ${ }^{46}$ bahwa gaya hidup seseorang mempengaruhi keputusan seseorang dalam melakukan pembelian. Gaya hidup seseorang bisa dilihat dari opininya terhadap barang tertentu. Jika barang tersebut dianggapnya baik, maka barang tersebut akan menjadi salah satu alternatif dalam melakukan pembelian, maka citra produk sangatah penting untuk membangun opini. Hal ini berarti bank BNI Syariah harus meyakinkan masyarakat luas bahwa produk dan kegiatan operasional bank sudah sesuai dengan prinsip syariah. Bank BNI Syariah harus menepis anggapan beberapa kalangan bahwa produk dan kegiatan opersional mereka sama saja dengan bank konvensional. Yang membedakan hanya label syariahnya saja.

\section{Pengaruh Religiusitas terhadap Keputusan Bertransaksi pada bank BNI Syariah Makassar}

45 Ekasari and Hartono, "Pengaruh Faktor-Faktor Gaya Hidup Konsumen Terhadap Keputusan Pembelian Laptop Apple."

${ }^{46}$ Nugroho J Setiadi, Perilaku Konsumen Perspektif Kontemporer Pada Motif, Tujuan Dan Keinginan Konsumen (Jakarta: Kencana Prenamedia Grup, 2013). 
Berdasarkan hasil analisis menunjukkan bahwa variabel Religiusitas berpengaruh terhadap keputusan bertransaksi pada bank BNI Syariah Makassar. Hal ini berarti hipotesis keempat yang menyatakan bahwa Religiusitas berpengaruh terhadap keputusan bertransaksi pada bank BNI Syariah Makassar diterima.Ini berarti nasabah yang memutuskan untuk bertransaksi pada BNI Syariah adalah nasabah yang memiliki tingkat keyakinan, ketaatan dan pemahaman terhadap Agama Islam relatif tinggi. Dapat disimpulkan bahwa label Syariah terhadap bank BNI Syariah Makassar sangat berpengaruh terhadap pengambilan keputusan, karena seseorang yang memiliki tingkat Religiusitas yang tinggi akan menggunakan produk barang atau jasa yang sesuai dengan ketentuan agama yang menjadi kepercayaan seseorang tersebut.

Hasil penelitian ini mendukung penelitian Shofwa (2013) ${ }^{47}$ yang mengatakan bahwa Religiusitas berpengaruh terhadap keputusan nasabah produk simpanan pada Bank Syariah Mandiri cabang Purwokerto. Dengan hasil penelitian yang menyatakan bahwa Religiusitas berpengaruh terhadap keputusan bertransaksi pada BNI Syariah Makassar, artinya bahwa jika tingkat Religiusitas masyarakat meningkat, maka akan berdampak pada keputusan masyarakat memilih lembaga keuangan syariah, salah satunya bank BNI Syariah Makassar. Hal ini sesuai dengan teori Religiusitas ${ }^{48}$ bahwa Religiusitas memiliki dimensi internal dan eksternal. Internal menyatakan identitas, sikap dan nilai. Sedangkan Eksternal menyatakan praktik ritual peribadatan yang mencerminkan aspek perilaku. Keduanya memiliki efek terhadap keputusan pembelian. Setiadi $(2015)^{49}$ menambahkan Religiusitas atau tingkat ketaatan dapat menjadi variabel yang sangat berguna dalam mengenalisis perilaku konsumen.

\section{PENUTUP}

Pertama, Psikografis aktivitas berpengaruh terhadap keputusan bertransaksi pada BNI Syariah Makassar. Ini berarti transaksi keuangan sudah menjadi kegiatan yang biasa dilakukan oleh masyarakat, baik dalam menunjang pekerjaan, menunjang hobbi, melakukan kegiatan jual beli, dan lain-lain. Apalagi produk yang ditawarkan oleh bank BNI Syariah Makassar sudah cukup banyak dan beragam, sehingga dapat menunjang aktivitas masyarakat di bidang keuangan.

47 Shofwa, "Pengaruh Kualitas Produk Dan Religiusitas Terhadap Keputusan Nasabah Produk Simpanan Pada BSM Cabang Purwokerto.”

48 Putra, Rossanty, and Gio, "Hubungan Antara Religiusitas dan Pengambilan Keputusan Membeli Panganan Halal Dimoderasi oleh Konsumen atas Risiko."

49 Setiadi, Perilaku Konsumen Perspektif Kontemporer Pada Motif, Tujuan Dan Keinginan Konsumen. 
Kedua, Psikografis minat tidak berpengaruh terhadap keputusan bertransaksi pada bank BNI Syariah Makassar. Hal ini berarti nasabah yang melakukan transaksi pada bank BNI Syariah tidak disebabkan oleh minat. Ada faktor lain seperti keterpaksaan, mengikuti aturan kerja atau aturan agama. apalagi keberadaan bank konvensional yang masih mendominasi dan tersebar hingga ke pedesaan membuat masyarakat masih lebih menyukai bank konvesinal. Menurut pengamatan penulis, kurangnya penggunaan media informasi juga menjadi salah satu faktor tidak berpengaruhnya minat terhadap keputusan bertransaksi pada bank BNI Syariah Makassar.

Ketiga, Psikografis Opini berpengaruh terhadap keputusan bertransaksi pada bank BNI Syariah Makassar. Hal ini berarti nasabah yang memutuskan untuk melakukan transaksi di bank BNI Syariah Makassar adalah nasabah yang berpendapat bahwa produk dan kegiatan operasional bank syariah benar-benar telah sesuai dengan prinsip syariah. Sehingga bank BNI Syariah Makassar beserta lembaga keuangan syariah seharusnya lebih giat untuk membangun image positif untuk mematahkan anggapan bahwa bank syariah dan bank konvensional sama saja.

Keempat, Religiusitas berpengaruh terhadap keputusan bertransaksi pada bank BNI Syariah Makassar. Hal ini berarti semakin tinggi tingkat keyakinan, ketaatan serta pemahaman masyarakat terhadap ajaran Islam, maka akan semakin mempengaruhi keputusan masyarakat dalam memilih bank atau lembaga keuangan. Tentunya, masyarakat yang memiliki tingkat Religiusitas tinggi akan memilih bank yang produk dan kegiatan operasionalnya berprinsip syariah, salah satunya bank BNI Syariah Makassar.

\section{DAFTAR PUSTAKA}

Abdillah, Thamrin. Manajemen Pemasaran. Jakarta: Raja Grafindo Persada, 2016.

A'yuni, Qurotul. "Pengaruh Identitas, Nilai dan Aktivitas Hijabers Community Terhadap Keputusan Pembelian Jilbab pada Butik Dian Pelangi Surabaya." Jurnal Pendidikan Tata Niaga (JPTN) 3, no. 2 (June 15, 2015). http://jurnalmahasiswa.unesa.ac.id/index.php/jptn/article/view/12077.

Bitar. "Pengertian, Bukti, Dan Jenis Transaksi Beserta Contohnya Secara Lengkap." GuruPendidikan.Com, December 1, 2016. http://www.gurupendidikan.co.id/pengertian-bukti-dan-jenis-transaksibeserta-contohnya-secara-lengkap/. 
Ekasari, Novita, and Rizky Hartono. "Pengaruh Faktor-Faktor Gaya Hidup Konsumen Terhadap Keputusan Pembelian Laptop Apple." Digest Marketing 2, no. 1 (2015): 65-71.

Engel, James F, Blackwell Roger D, and W Minia Paul. Perilaku Konsumen Jilid 1. Jakarta: Binarupa Aksara, 1994.

Ghozali, Imam. Aplikasi Analisis Multvariate Dengan Program SPSS. Semarang: Badan Penerbt Undip, 2006.

Kotler, and Armstrong. Prinsip-Prinsip Pemasaran. Jakarta: Erlangga, 2001.

Kotler, P, and K Keller. Manajemen Pemasaran. Jakarta: Indeks, 2008.

Listyorini, Sari. "Analisis Faktor-Faktor Gaya Hidup Dan Pengaruhnya Terhadap Pembelian Rumah Sehat Sederhana (Studi Pada Pelanggan Perumahan Puri Dinar Mas PT. Ajisaka Di Semarang)." Jurnal Administrasi Bisnis 1, no. 1 (September 30, 2012): 12-24.

Malik, Abdul. "Ini Penyebab Pangsa Pasar Perbankan Syariah Tembus 5,46 Persen Pada Juli 2017." Accessed November 19, 2017. https://m.bareksa.com/id/text/2017/09/22/ini-penyebab-pangsa-pasarperbankan-syariah-tembus-546-persen-pada-juli-2017/16717/news.

Mowen, J.C, and Minor. Perilaku Konsumen. Jakarta: Erlangga, 2002.

Noor, Juliansyah. Metode Penelitian Skripsi, Tesis, Disertasi, Dan Karya Ilmiah. Jakarta: Kencana, 2010.

Prasetijo, Ihalaw. Perilaku Konsumen. Yogyakarta: Andi, 2004.

Putra, M Dharma Tuah, Rossie Rossanty, and Prana Ugiana Gio. "Hubungan Antara Religiusitas dan Pengambilan Keputusan Membeli Panganan Halal Dimoderasi oleh Konsumen atas Risiko." Jurnal ilmiah Research Sains 2, no. 2 (2016): 7-13.

Rinawiyanti, Esti Dwi, Rosita Meitha, and Jeremia Januar Pratama Putra. "Studi Segmentasi Berorientasikan Psikografis dan Behavioral pada Konsumen Fitness Center di Surabaya." JIEMS Journal of Industrial Engineering and Management Systems) 7, no. 1 (March 16, 2017): 25-38. doi:10.30813/jiems.v7i1.107.

Roza, Suswita. "Analisis Pengaruh Gaya Hidup Terhadap Keputusan Konsumen Memilih Eco Product (Studi Kasus Pada Konsumen Tupperware Di Kota Jambi) Jurnal Penelitian Universitas Jambi: Seri Humaniora." Jurnal Penelitian Universitas Jambi: Seri Humaniora 16, no. 2 (2014): 47-58. 
Sandy, Kunthi Fahmar. "Pangsa Pasar Keuangan Syariah Tembus 8\%." SINDOnews.com. Accessed October 29, 2017. https://ekbis.sindonews.com/read/1252673/178/pangsa-pasarkeuangan-syariah-tembus-8-1509271447.

Saputri, Marheni Eka. "Perilaku Konsumen Terhadap Pembelian Online Produk Fashion Pada Zalora Indonesia." Jurnal Sosioteknologi 15, no. 2 (August 30, 2016): 291-97. doi:10.5614/sostek.itbj.2016.15.02.11.

Sari, Elisa Valenta. "Aset Empat Bank BUMN Syariah Mekar Sepanjang 2016." Ekonomi. Accessed November 19, 2017. https://www.cnnindonesia.com/ekonomi/20170306074642-78198035/aset-empat-bank-bumn-syariah-mekar-sepanjang-2016.

Setiadi, Nugroho J. Perilaku Konsumen Perspektif Kontemporer Pada Motif, Tujuan Dan Keinginan Konsumen. Jakarta: Kencana Prenamedia Grup, 2013.

Shofwa, Yoiz. "Pengaruh Kualitas Produk Dan Religiusitas Terhadap Keputusan Nasabah Produk Simpanan Pada BSM Cabang Purwokerto." Laporan Penelitian, IAIN Purwokerto, 2015.

Sumarwn, Ujang. Perilaku Konsumen Teori Dan Penerapannya Dalam Pemasaran. Jakarta: Ghalia Indonesia, 2005.

Sutrisno. "Membangun Model Lembaga Keuangan Syariah." Jurnal Ekonomi Dan Bisnis Islam 7, no. 2 (n.d.): 139-49.

Walker, Boyd L. Manajemen Pemasaran. Jakarta: Erlangga, 1997. 